\title{
PENGARUH BIAYA DISTRIBUSI TERHADAP PENINGKATAN VOLUME PENJUALAN JASA BARANG DI JNE KUNINGAN
}

\author{
Cahyat Rohyana \\ Program Studi D4 Akuntansi Keuangan \\ Politeknik Pos Indonesia \\ cahyatrohyana@poltekpos.ac.id
}

\begin{abstract}
ABSTRAK
PT Tiki Jalur Nugraha Ekakurir atau yang sering kita kenal dengan JNE EXPRESS merupakan perusahaan swasta asal indonesia, yang bergerak dalam bidang jasa pengiriman logistik yang berpusat di Jakarta. Dibawah nama resmi yang berlabel Tiki Jalur Nugraha Ekakurir adalah perusahaan pengiriman terbesar di Indonesia. Penelitian ini bertujuan untuk mengetahui pengaruh antara biaya distribusi terhadap peningkatan volume penjualan jasa barang baik secara masing-masing ataupun bersamaan di JNE Kuningan. Metode yang digunakan dalam penelitian ini adalah metode kuantitatif dengan jenis perumusan masalah asosiatif yang memiliki suatu hubungan sebab akibat (klausal). Dalam Penelitian ini menggunakan data sekunder berupa laporan keuangan JNE Kuningan serta populasi yang digunakan dalam penelitian ini adalah seluruh laporan keuangan JNE Kuningan dari awal berdirinya sampai dengan sekarang dengan pengambilan sampel menggunakan metode nonprobability sampling dengan teknik purposive sampling. Teknik analisis data yang digunakan dalam penelitian ini diantaranya analisis deskriptif, korelasi product moment, regresi linier sederhana, koefisien determinasi, dan juga uji t. Hasil penelitian menunjukan bahwa biaya distribusi secara parsial terdapat pengaruh yang signifikan terhadap volume penjualan.
\end{abstract}

Kata Kunci: Biaya, Biaya Distribusi, Penjualan, Volume Penjualan

\begin{abstract}
PT Tiki Jalur Nugraha Ekakurir or what we often know JNE EXPRESS is a private company from Indonesia, which is engaged in logistics delivery services based in Jakarta. Under the officially labeled name Tiki Jalur Nugraha Ekakurir is the largest shipping company in Indonesia. This study aims to determine the effect of distribution cost on increase sales volume of goods services in JNE Kuningan. The method use in this research is quantitative method with the type of associative problem formulation that has a causal relationship. In this research using secondary data in the form of JNE Kuningan financial statements and the population used in this study are all financial statements of JNE Kuningan from its inception until now with sampling using the method nonprobability sampling with purposive sampling technique. The data analysis techniques used in this study were descriptive statistics, product moment correlation, simple linear regression, coefficient of determination, and t test. The result showed that partially distribution cost had a significant effect on sales volume.
\end{abstract}

Keyword: Cost, Distribution Cost, Sales, Sales Volume

PENDAHULUAN

https://ejurnal.poltekpos.ac.id/index.php/jurnalland | 95 
Pada era modernisasi kini dalam dunia bisnis dimana tingkat persaingannya makin tinggi baik di dalam segi lokal maupun global, yang secara tidak langsung menuntut perusahaan atau badan usaha untuk harus memiliki kinerja yang sangat baik dalam persaingan bisnis agar perusahaan tersebut dapat bertahan. Perusahaan bisa disebut sebagai sarana yang salah satunya bisa mendukung program yang dibuat oleh pemerintah dalam berbagai segi perekonomian yang kini perusahaan-perusahaan banyak berdiri muncul beragam dalam bentuk sebuah usaha atau bisnis, yang menunjukan dunia bisnis kini semakin berkembang. Untuk mengembangkan sebuah bisnis, terdapat beberapa unsur yang harus di perhatikan perusahaan di dalams sebuah manajemen pemasarannya diantaranya yakni produk, harga, promosi, dan distribusi.

Menurut (Sendouw \& Soepeno, 2018:1089) "Tujuan perusahaan didirikan yakni untuk meningkatkan volume penjualan, mempertinggi daya saing dan meminimalkan biaya produksi untuk mencapai laba maksimal.". Setiap perusahaan pasti memiliki suatu tujuan, walaupun antara perusahaan pasti tidak akan sama, namun secara umum tujuan dari perusahaan ialah untuk memperoleh laba yang setinggi-tingginya agar perusahaan tersebut dapat mempertahankan kelangsungan hidupnya.

Salah satu faktor agar tujuan perusahaan dapat tercapai adalah dapat dipengaruhi oleh penjualan dalam memaksimalkan pendapatan atau memperoleh laba adalah dari segi distribusi. Distribusi merupakan kegiatan yang dipergunakan untuk menyampaikan sebuah produk kepada seorang konsumen, yang akhirnya konsumen tidak perlu tahu cara pengangkutan barang yang sudah dibelinya. Secara umum menurut tjiptono dalam (Sendouw \& Soepeno, 2018:1090) "distribusi bisa diartikan sebagai suatu kegiatan pemasaran yang berusaha memperlancar dan mempermudah penyampaian barang dan jasa dari produsen kepada komsumen.”. Distribusi sebuah produk yang cepat dan tentunya tepat akan sangat berpengaruh pada penjualan karena berkaitan dengan kepercayaan konsumen pada produk yang dijual oleh produsen tersebut. Dalam praktiknya, proses distribusi memerlukan sebuah alat transportasi agar dapat mengirimkan suatu barang dari tempat ke tempat yang lainnya. Dimana dapat disimpulkan bahwa penggunaan alat transportasi sebagian besar saling berhubungan dengan aktivitas manusia sehari-hari, yang mana dapat lebih memudahkan manusia dalam berpindah tempat atau juga memindahkan suatu barang ke tujuan tertentu.

Indonesia ialah negara yang di juluki kepulauan terbesar di dunia, terdiri dari banyaknya pulau dari Sabang sampai dengan Merauke. Luasnya negara kita ini mengakibatkan kita mengharuskan mencari cara agar tetap terhubung antara daerah satu dengan lainnya yakni dengan cara memanfaatkan alat transportasi guna memenuhi kebutuhan manusia yang tersebar dipenjuru pulau di Indonesia. Sebuah jasa pelayanan logistik merupakan media penghubung yang tepat antara produsen dan konsumen dalam mengirimkan atau memindah barangkan dari tempat ke tempat yang lainnya. Yang mana hal tersebut adalah dasar cikal bakal tumbuh dan berkembangnya perusahaan-perusahaan logistik di Indonesia.

Pertumbuhan dan perkembangan industri logistik di Indonesia akan dipengaruhi oleh teknologi dan pesaing baru seiring dengan pertumbuhan ekspektasi konsumen terhadap model bisnis yang inovatif dalam layanan logistik yang tentunya dapat menaikan tingkat pertumbuhan industri logistik di Indonesia, seperti yang terjadi di industri logistik Indonesia saat ini yang dikutip dari media wartaekonomi.co.id dimana Frost \& Sullivan sebagai direktur konsultan transportasi dan logistik di Indonesia memperkirakan bahwa pertumbuhan industri logistik di Indonesia akan tumbuh sebesar $6,5 \%$ hingga pada tahun 2022. Dalam hal tersebut semakin memperkuat bahwa tingkat industri logistik di 
Indonesia akan semakin meningkat setiap tahunnya dan menjadikan industri logistik sebagai peluang usaha yang menjanjikan pada saat ini.

Berikut ini ialah fenomena yang terjadi dalam industri jasa logistik dimana terlihat perbandingan persentase top brand index jasa logistik yang ada di Indonesia tahun 2015 sampai dengan tahun 2020:

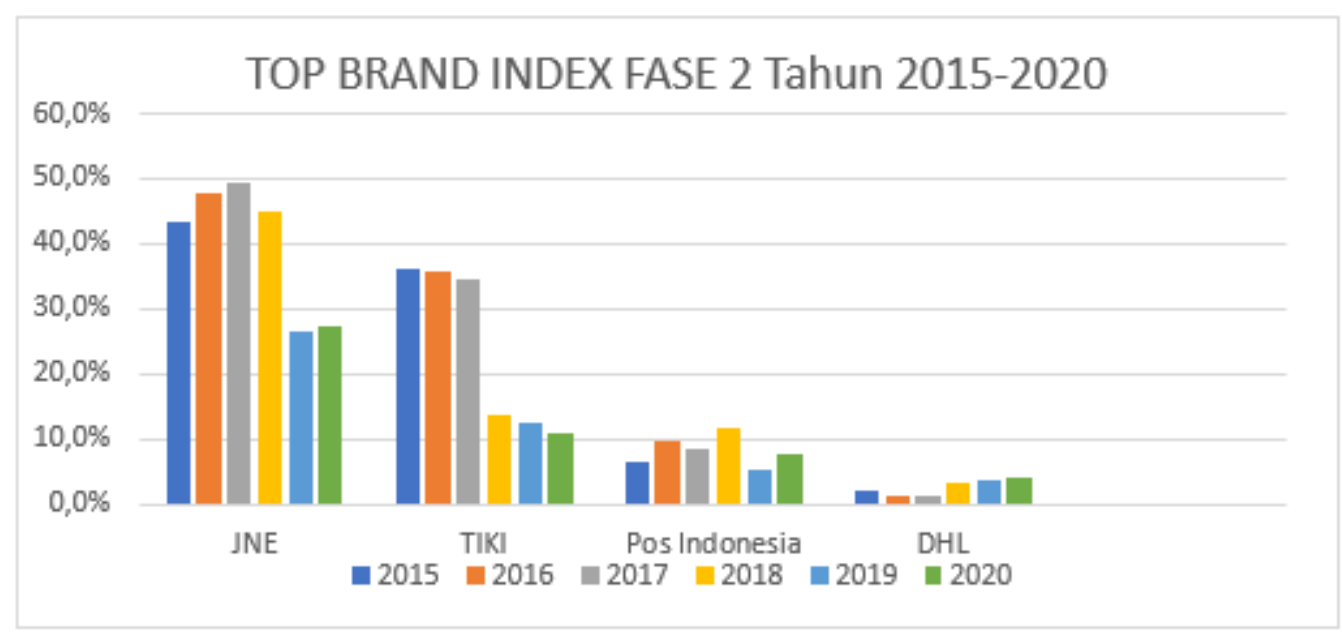

Sumber: www.topbrand-award.com (data diolah)

Top Brand Index merupakan penilaian sebuah brand yang dilakukan dengan survei secara independen oleh Frontier Research yang telah dipercaya oleh para pemilik merek dan pelanggan di Indonesia dengan indikator hasil survei berasal dari 3 parameter yakni top of mind share, top of market share, dan top of commitment share. Dari tabel grafik Top Bran Index diatas dapat diambil kesimpulan bahwa persentase market share atau volume penjualan dari perusahaan logistik di Indonesia dari tahun ke tahun selanjutnya terjadi fluktuatif. Adapun yang menjadi penyebab terjadinya penurunan volume penjualan di perusahaan jasa ekspedisi, seperti banyak munculnya pesaing dalam industri logistik di Indonesia, banyaknya perusahaan jasa ekspedisi baru yang mengakibatkan dituntutnya perusahaan agar bisa unggul dalam persaingan. Lalu naiknya harga surat muatan udara (SMU) secara nasional pada tahun 2019 yang menyebabkan seluruh perusahaan ekspedisi yang secara otomatis menaikan harga sehingga mengurangi volume penjualan karena konsumen lebih memilih untuk mempunyai harga yang paling murah. Dan juga terjadi pada tahun 2020 yang mana terjadi maraknya pandemi covid-19 menyebabkan volume penjualan menurun dan perusahaan harus mengeluarkan biaya distribusi lebih untuk surat jalan pada masa pandemi.

Pada tahun 2019, seperti yang di lansir dalam batamnews.com (https://www.batamnews.co.id/berita-43843-omset-turun-hingga-70-persen-asperindo-initsunami-bisnis-ekspedisi.html), JNE mengalami penurunan jumlah volume penjualan dari tahun sebelumnya khususnya di JNE Batam yang mengakibatkan omset laba pada tahun 2019 menurun sekitar 50\%-70\%. Hal tersebut terjadi dikarenakan karena dipicunya naiknya biaya jasa pengiriman atau distribusi seiring dengan kenaikan harga Surat Muatan Udara (SMU) karena saat itu komposisi pengiriman lewat udara masih mendominasi sebesar $60 \%$ dan $40 \%$ sisanya menggunakan jalur darat. Sehingga dapat diambil kesimpulan bahwa JNE batam mengalami kenaikan biaya distribusi walaupun sebenarnya tingkat laba yang diperoleh menurun dari tahun sebelumnya yang pada hakikatnya seharusnya ketika omset atau laba perusahaan yang di dapat sedang turun, 
seharusmya perusahaan menurunkan atau mengefisienkan biaya distribusi yang dikerluarkan untuk menekan biaya yang keluar supaya laba akan menaik kembali.

Fenomena serupa dialami pada tahun 2020, seoerti yang dikutip dari tribunnews.com (https://banjarmasin.tribunnews.com/2020/06/29/wajib-surat-rapid-test-masuk-kaltengpengusaha-ekspedisi-akui-alami-penurunan-omzet-20-persen), menyebutkan bahwa perusahaan logistik PT Borneo Arta mandiri (BAM Cargo) mengalami penurunan omset sekitar 20\%. Hal tersebut dikarenakan pada masa pandemi covid 19 dengan adanya kebjikan sopir atau kurir harus membawa surat rapid test yang cukup mengganggu sehingga menjadi masalah bagi perusahaan karena harus mengeluarkan biaya pembuatan surat tersebut yang mana dalam membuat surat tersebut dironggoh kocek sebesar $\mathrm{Rp}$ 450.000 dan berlaku hanya 10 hari saja dan harus membuat kembali ketika masa berlakunya telah habis. Sehingga dapat diambil kesimpulan bahwa perusahaan logistik PT Borneo Arta mandiri (BAM Cargo) mengalami penurunan omset sebesar 20\%, dan juga mengalami kenaikan biaya distribusi akibat adanya pandemi covid 19 ini, walaupun tingkat laba yang diperoleh menurun dari tahun sebelumnya yang seharusnya ketika omset atau laba perusahaan yang di dapat sedang turun, seharusmya perusahaan menurunkan atau mengefisienkan biaya distribusi yang dikerluarkan untuk menekan biaya yang keluar supaya laba akan menaik kembali.

Lalu terdapat fenomena yang berkaitan langsung dengan tempat peneliti melangsungkan penelitian di JNE Kuningan, perkembangan agen JNE Kuningan yang berawal membawahi sekitar 7 agen pada tahun 2016 dan sekarang pada tahun 2020 membawahi sekitar 27 agen di seluruh Kabupaten Kuningan, jika dilihat dari luas wilayah kabupaten Kuningan sendiri yang cukup luas dan terdiri dari 32 kecamatan jumlah agen tersebut masih kurang yang menyebabkan kurang optimal nya dalam peningkatan volume penjualan, karena masih ada daerah yang belum terjangkau oleh JNE Kuningan dalam melayani Jasa Ekspedisinya.

Dalam penelitian ini, peneliti termotivasi untuk melakukan penelitian mengenai bagaimana biaya distribusi dapat mempengaruhi peningkatan volume penjualan, khususnya dalam penjualan jasa barang di JNE Kuningan. Sebagaimana dilihat dari penelitian lama yang sangat relevan dengan penelitian ini ialah penelitian yang sudah diteliti oleh (Rasyid \& Suzan, 2018:1) yang mana "biaya distribusi memiliki pengaruh yang signifikan dengan arah positif terhadap penjualan perusahaan manufaktur sektor food and beverage yang terdaftar di Bursa Efek Indonesia tahun 2012-2016. “.

Berdasarkan uraian latar belakang yang ada, maka penulis merumuskan identifikasi masalah dalam penelitian ini adalah sebagai berikut

1. Bagaimanakah biaya distribusi di JNE Kuningan?

2. Bagaimanakah peningkatan volume penjualan jasa barang di JNE Kuningan?

3. Bagaimanakah pengaruh biaya distribusi terhadap peningkatan volume penjualan jasa barang di JNE Kuningan?

\section{KAJIAN PUSTAKA}

\section{Biaya}

Menurut (Lanen et al., 2017:58) "Biaya (cost) adalah pengorbanan yang dilakukan untuk mendapatkan sumber daya." Didukung juga oleh teori menurut (Mulyadi, 2015:7) yang menyebutkan bahwa "Biaya adalah pengorbanan sumber ekonomis yang diukur dalam satuan uang, yang telah terjadi, sedang terjadi atau yang kemungkinan akan terjadi untuk tujuan tertentu.". 


\section{Biaya Distribusi}

Menurut Ardiyoso dalam (Putra et al., 2016:2) adalah "biaya yang terjadi guna memasarkan atau mengirimkan suatu produk." Selain itu di dukung juga oleh teori lain yang dikemukakan oleh Mulyadi dalam (Subagyo et al., 2018) yang menyebutkan bahwa"biaya distribusi adalah jumlah total biaya saluran distribusi yang meliputi semua kegiatan yang berhubungan dengan usaha untuk menyampaikan barang-barang produksi ke suatu perusahaan dari produksi kepada para pembeli atau calon pembeli.".

\section{Penjualan}

Menurut teori Basu Swastha dalam (Gusrizaldi \& Komalasari, 2016:292) "Penjualan merupakan ilmu dan seni mempengaruhi pribadi yang dilakukan oleh penjual untuk mengajak orang lain bersedia membeli barang atau jasa yang ditawarkan." Selain itu juga di dukung juga oleh teori lain yang dikemukakan oleh Philip Kotler dalam (Gusrizaldi \& Komalasari, 2016:292) yang mana menyebutkan "penjualan adalah ilmu dan seni mempengaruhi pribadi pribadi dan dipersuaikan oleh penjualan untuk mengajak orang lain agar bersedia membeli barang yang ditawarkan.”.

\section{Volume Penjualan}

Menurut teori Swastha dalam (Saragih, 2017:2) "Volume penjualan merupakan penjualan bersih dari laporan laba perusahaan. Penjualan bersih diperoleh melalui hasil penjualan seluruh produk (produk lini) selama jangka tertentu, dan hasil penjualan yang diperoleh dari market share (pangsa pasar) yang merupakan penjualan potensial, yang dapat terdiri dari kelompok teritorial dan kelompok pembeli saham jangka waktu tertentu." Selain itu di dukung juga oleh teori lain yang dikemukakan oleh Guitinan dalam (Kurnia, 2017:170) yang menyebutkan bahwa "volume penjualan adalah besarnya kapasitas produk atau jasa yang dijual.".

\section{METODE PENELITIAN}

\section{Jenis Penelitian}

Metode kuantitatif merupakan metode yang digunakan penulis dalam penelitian ini. Menurut (Sugiyono, 2017) "Metode penelitian kuantitatif dapat diartikan sebagai metode penelitian yang berlandaskan pada filsafat positivisme, digunakan untuk meneliti pada populasi atau sampel tertentu, pengumpulan data menggunakan instrumen penelitian, analisis data bersifat kuantitatif/statistik, dengan tujuan untuk menguji hipotesis yang telah ditetapkan". Peneliti menggunakan jenis penelitian yang kuantitatif dengan metode asosiatif yang berbentuk hubungan sebab akibat (kausal). Menurut Sugiyono (Sugiyono, 2017) "rumusan masalah asosiatif adalah suatu rumusan masalah penelitian yang bersifat menanyakan hubungan antara dua variabel atau lebih". (Sugiyono, 2017a) "hubungan kausal adalah hubungan yang bersifat sebab akibat. Jadi disini ada variabel independen (variabel yang mempengaruhi) dan dependen (dipengaruhi).”.

\section{Teknik Pengumpulan Data}

Teknik pengumpulan data dalam penelitian kali ini ialah dengan menggunakan teknik studi dokumentasi, maka data yang diperoleh penulis ialah data sekunder berupa data biaya distribusi dan volume penjualan periode tahun 2017-2019 yang diperoleh dari laporan keuangan JNE Kuningan yang diambil dari perusahaan.

\section{Populasi dan Sampel}


Populasi di dalam penelitian ini ialah seluruh Laporan Keuangan JNE Kuningan dari semenjak berdiri sampai dengan sekarang. Teknik sampling dalam penelitian kali ini ialah nonprobability sampling dengan teknik sampling purposive. Dimana sampel yang diolah dalam penelitian ini ialah bagian dari jumlah populasi pada yang ada laporan keuangan di kantor JNE Kuningan yaitu laporan keuangan laba rugi perbulan pada periode 2017 sampai 2019.

\section{Teknik Analisis Data}

Teknik analisis data dalam penelitian kali ini diantaranya ialah Statistik Deskriptif. Teknik ini dipergunakan untuk mengetahui mengenai beberapa rumusan masalah yang berisi tentang deskripsi masing masing variabel. Analisis Korelasi Product Moment yang dipergunakan ini untuk mengetahui hubungan arah dan kuatnya dari masing-masing variabel independen dengan variabel dependen. Analisis regresi linier sederhana dipergunakan untuk mengetahui arah hubungan antara variabel independen dengan variabel dependen, yang mana apakah variabel independen menunjukan hubungan yang positif ataukah negatif untuk melihat variabel dependen mengalami kenaikan atau penurunan atas hasil dari variabel independen. Koefisien Determinasi, dipergunakan untuk mengukur besarnya presentase pengaruh semua variabel independen dalam model regresi terhadap variabel dependennya. Dan yang terakhir ialah Uji t, dipergunakan untuk menguji signifikansi hubungan secara terpisah, yaitu apakah hubungan tersebut yang ditemukan berlaku untuk seluruh populasi, maka perlukan uji signifikansinya. Dalam penelitian ini juga, peneliti menggunakan sebuah aplikasi SPSS (Satistical Package for the Social Sciences) versi 25.0 agar mendapatkan hasil yang lebih akurat.

\section{HASIL DAN PEMBAHASAN}

\section{Statistik Deskriptif}

Tabel 1

Hasil Statistik Deskriptif

\begin{tabular}{|c|c|c|c|c|}
\hline \multicolumn{5}{|c|}{ Descriptive Statistics } \\
\hline & $\mathrm{N}$ & Minimum & Maximum & Mean \\
\hline Biaya Distribusi & 36 & 20376790 & 35857145 & 26851460,06 \\
\hline Volume Penjualan & 36 & 113981300 & 1198706500 & 410264604,50 \\
\hline Valid N (listwise) & 36 & & & \\
\hline
\end{tabular}

Sumber: Output SPSS versi 25, data diolah (2020).

Dari hasil pengolahan data menggunakan aplikasi SPSS versi 25 diatas maka dapat terlihat nilai minimum, maksimum dan rata-rata dari biaya distrusi dan volume penjualan dari laporan laba rugi bulanan JNE Kuningan yang di dapat, maka dapat disimpulkan bahwa nilai minimum dari biaya distribusi adalah Rp. 20.376 .790 dan nilai maksimumnya ialah sebesar Rp. 35.857.145 dan rata-rata dari biaya distribusi menunjukkan nilai sebesar Rp. 26.851.460,06 , selain itu volume penjualan mempunyai nilai minimumnya sebesar Rp. 113.981 .300 dan nilai maksimumnya menunjukkan angka Rp. 1.198.706.500 dan mempunyai rata-rata sebesar Rp. 410.264.604,50.

\section{Analisis Korelasi Product Moment}


Tabel 2

Hasil Analisis Korelasi Product Moment

\begin{tabular}{|c|c|c|c|}
\hline \multicolumn{4}{|c|}{ Correlations } \\
\hline & & Biaxa Distribusi & Volume Peniuxalan \\
\hline \multirow[t]{3}{*}{ Biaxa Distribusi } & Pearson Correlation & 1 & $.896^{\circ *}$ \\
\hline & Sig. (-tailed) & & .000 \\
\hline & $\mathrm{N}$ & 36 & 36 \\
\hline \multirow{3}{*}{$\begin{array}{l}\text { Volume } \\
\text { Deniualan }\end{array}$} & Pearson Correlation & $.896^{* *}$ & 1 \\
\hline & Sig. (2-tailed) & .000 & \\
\hline & $\mathrm{N}$ & 36 & 36 \\
\hline
\end{tabular}

Sumber: Output SPSS versi 25, data diolah (2020)

Dari hasil pengolahan data menggunakan aplikasi SPSS versi 25 diatas dapat diketahui bahwa koefisien korelasi antara variabel independen yaitu biaya distribusi (X) terhadap variabel dependen yaitu volume penjualan (Y) menghasilkan nilai $\mathrm{r}$ dalam angka sebesar 0,896 yang dimana menunjukan bahwa dalam tabel interpretasi koefisien korelasinya masuk kedalam koefisien interval $0,800-1,000$ yang artinya memiliki hubungan yang sangat kuat.

\section{Analisis Regresi Linier Sederhana}

Tabel 3

Hasil Analisis Regresi Linier Sederhana

\begin{tabular}{|c|c|c|c|c|c|}
\hline \multicolumn{6}{|c|}{ Coefficients $\mathrm{a}^{\mathrm{a}}$} \\
\hline \multirow[b]{2}{*}{ Model } & \multicolumn{2}{|c|}{ Unstandardized Coefficients } & \multirow{2}{*}{$\begin{array}{c}\text { Standardized } \\
\text { Coefficients } \\
\text { Beta }\end{array}$} & \multirow[t]{2}{*}{ 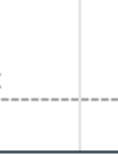 } & \multirow{2}{*}{ Sig. } \\
\hline & B & Std. Error & & & \\
\hline \multirow[t]{2}{*}{ (Constant) } & \multicolumn{3}{|c|}{$\begin{array}{l}-122674977.61 \\
\end{array}$} & \multirow[t]{2}{*}{-8.188} & \multirow[t]{2}{*}{.000} \\
\hline & 1004479495.436 & & 3 & & \\
\hline Biaxa Distribusi & 52.688 & & & 11.739 & .000 \\
\hline
\end{tabular}

Sumber: Output SPSS versi 25, data diolah (2020)

Dari hasil pengolahan data menggunakan aplikasi SPSS versi 25 diatas, dapat dilihat konstanta sebesar - 1.004.479.495,436, nilai koefisien regresi biaya distribusi (b) sebesar 52,688 . Sehingga dapat diketahui persamaan regresi antara biaya distribusi terhadap volume penjualan adalalah sebagai berikut:

$$
\mathrm{Y}=-1.004 .479 .495,436+52,688 \mathrm{X}
$$

Dari persamaan tersebut dapat diartikan, jika nilai variabel biaya distribusi $(\mathrm{X})=0$, maka nilai variabel volume penjualan (Y) adalah sebesar Rp. -1.004.479.495,436. Selain 
itu jika nilai variabel biaya distribusi (X) mengalami kenaikan sebesar Rp. 1, maka nilai variabel volume penjualan (Y) akan mengalami kenaikan sebesar Rp. 52,688.

\section{Analisis Koefisien Determinasi}

\section{Tabel 4}

\section{Hasil Analisis Koefisien Determinasi}

\begin{tabular}{|l|cc|c|c|}
\hline & & & \multicolumn{3}{c|}{ Model Summary } \\
\hline Model & $\mathrm{R}$ & R Square & $\begin{array}{c}\text { Adjusted R } \\
\text { Square }\end{array}$ & Std. Error of the Estimate \\
\hline 1 & $.896^{\mathrm{a}}$ & .802 & .796 & 137574085.034 \\
\hline a. Predictors: (Constant), Biaxa Distribusi & & \\
\hline b. Dependent Variable: Volume Peniualan & & \\
\hline
\end{tabular}

Sumber: Output SPSS versi 25, data diolah (2020)

Dari hasil pengolahan data menggunakan aplikasi SPSS versi 25 diatas, dapat diketahui bahwa nilai R2 sebesar 0,802 atau sebesar $80,2 \%$ yang menunjukan bahwa persentase pengaruh variabel independen (Biaya Distribusi) terhadap variabel dependen (Volume Penjualan) adalah sebesar 80,2\% sedangkan 19,8\% sisanya dipengaruhi oleh variabel lain yang tidak diujikan dalam penelitian ini.

\section{Uji t}

Tabel 5

\section{Uji Parsial (Uji t)}

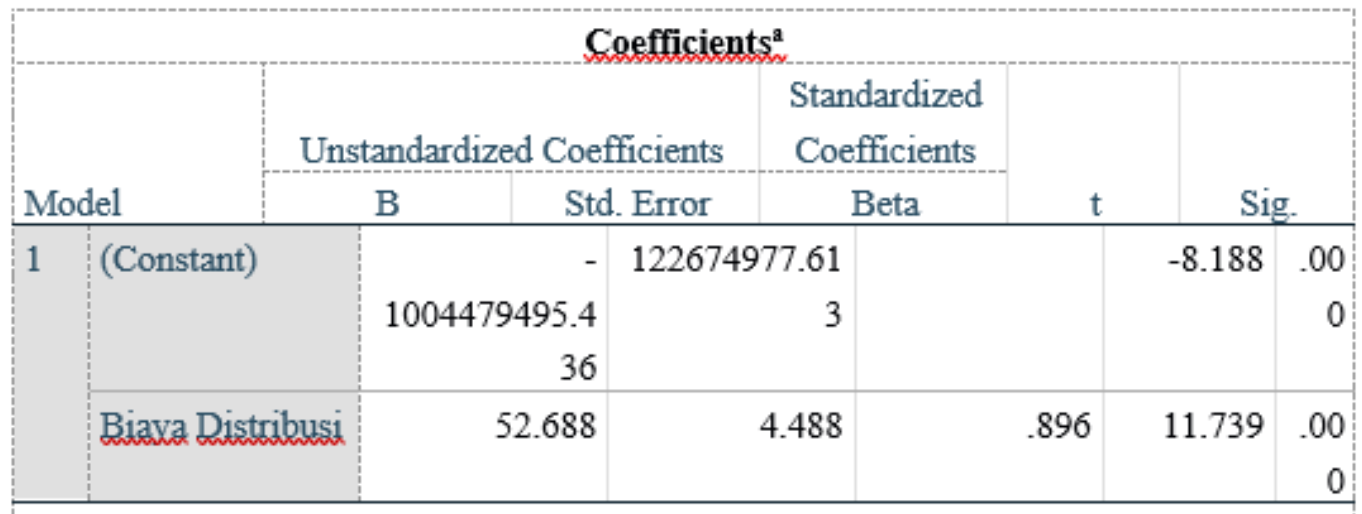

a. Dependent Variable: Volume Peniualan

Sumber: Output SPSS versi 25, data diolah (2020)

Dari hasil pengolahan data menggunakan aplikasi SPSS versi 25 diatas, dapat kita ketahui thitung untuk variabel biaya distribusi adalah sebesar 11,739 dengan derajat kebebasan sebesar 34 (n-k yaitu 36-2), dengan pengujian dua pihak dimana tingkat signifikansi 5\% atau 0,05 maka didapat ttabel sebesar 2,032, sehingga thitung lebih besar daripada ttabel (thitung 11,739 > ttabel 2,032). Sedangkan untuk angka signifikansi biaya distribusi sebesar $0,000<0,05$. Maka dapat disimpulkan bahwa Ho ditolak dan Ha 
diterima. Artinya terdapat pengaruh yang signifikan antara biaya distribusi terhadap peningkatan volume penjualan. Dengan gambar kurva uji t sebagai berikut:

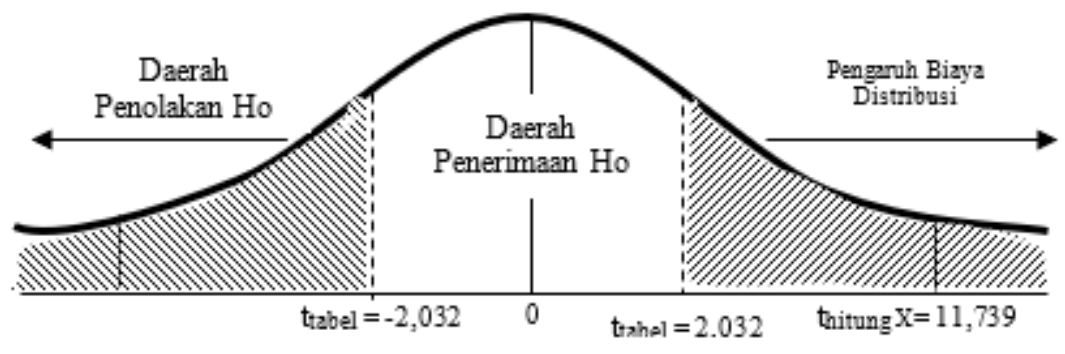

\section{Gambar 1 Kurva Distribusi X Terhadap Y \\ Biaya Distribusi di JNE Kuningan}

Dari data yang di dapatkan peneliti dari data sekunder berupa laporan laba rugi bulanan dari tahun 2017 sampai dengan tahun 2019, perkembangan biaya distribusi di JNE Kuningan di setiap bulannya terjadi adanya kenaikan dan penurunan atau mengalami fluktuasi disetiap bulannya. Dari hasil output menggunakan aplikasi SPSS versi 25, terdapat nilai minimum, nilai maksimum dan rata-rata dari biaya distrubusi dari JNE Kuningan yang di dapat, maka dapat disimpulkan bahwa nilai minimum dari biaya distribusi adalah Rp. 20.376.790 dan nilai maksimumnya ialah sebesar Rp. 35.857.145 dan rata-rata dari biaya distribusi menunjukkan nilai sebesar Rp. 26.851.460,06. Di bawah ini merupakan grafik yang menggambarkan dari analisis diatas sebagai berikut:

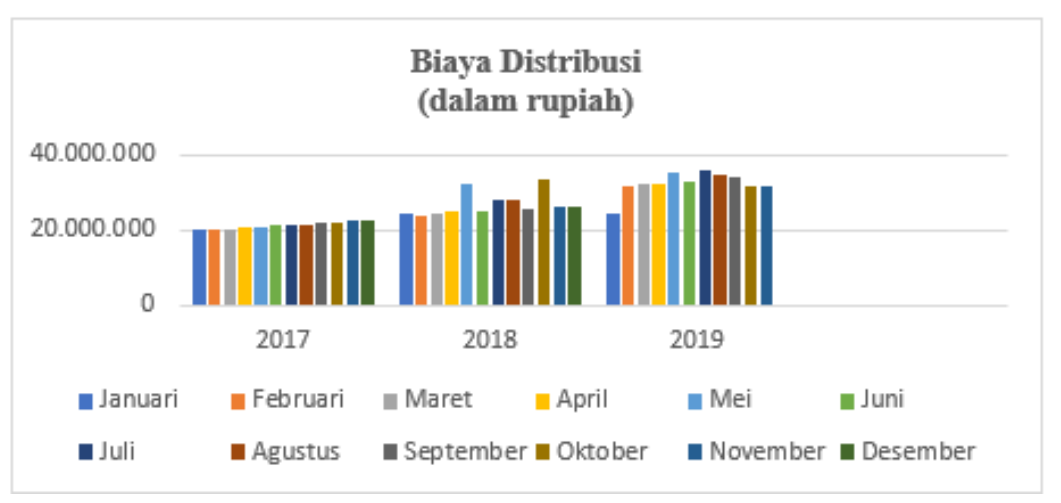

Gambar 2 Diagram Biaya Distribusi di JNE Kuningan (Periode 2017-2019)

\section{Peningkatan Volume Penjualan Jasa Barang di JNE Kuningan}

Dari data yang di dapatkan peneliti dari data sekunder berupa laporan laba rugi bulanan dari tahun 2017 sampai dengan tahun 2019, perkembangan volume penjualan di JNE Kuningan di setiap bulannya terjadi adanya kenaikan dan penurunan atau mengalami fluktuasi disetiap bulannya. Dari hasil output menggunakan aplikasi SPSS versi 25, terdapat nilai minimum, nilai maksimum dan rata-rata dari volume penjualan dari JNE Kuningan yang di dapat, maka dapat disimpulkan bahwa nilai minimum dari volume penjualan adalah sebesar Rp. 113.981.300 dan nilai maksimumnya menunjukkan angka Rp. 1.198.706.500 dan mempunyai rata-rata sebesar Rp. 410.264.604,50. Dibawah ini merupakan diagram yang menggambarkan dari analisis diatas sebagai berikut: 


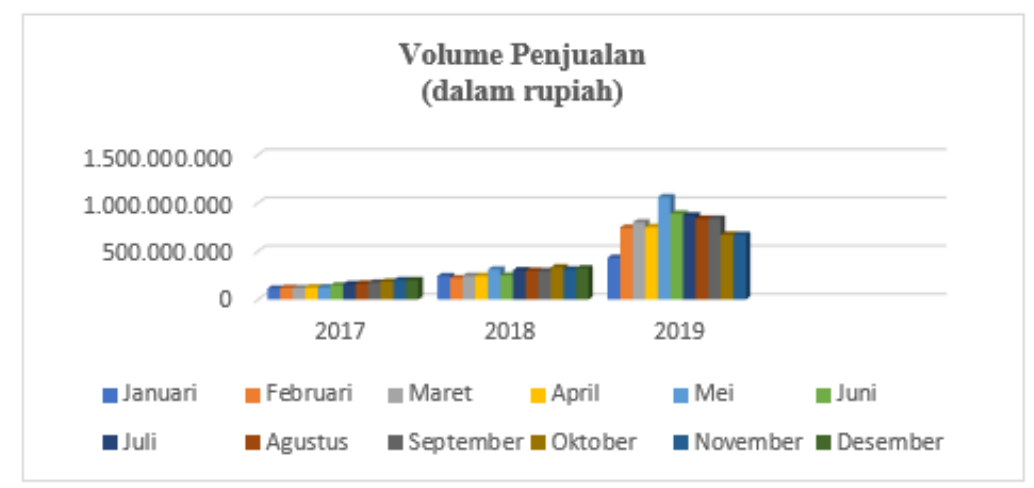

Gambar 3 Diagram Volume Penjualan di JNE Kuningan (Periode 2017-2019)

\section{Pengaruh Biaya Distribusi Terhadap Peningkatan Volume Penjualan Jasa Barang di JNE Kuningan}

Berdasarkan hasil analisis yang dilakukan dari perhitungan menggunakan program aplikasi SPSS versi 25, uji t secara parsial menunjukan bahwa variabel biaya distribusi mempunyai thitung $=11,739$ dan ttabel $=2,032$ yang berarti (thitung $>$ ttabel) dan taraf signifikansi sebesar 0,000 yang lebih kecil dari signifikansi 0,05 yang mana hal tersebut menunjukan bahwa hipotesis Ho ditolak dan Ha diterima, yang berarti secara parsial terdapat pengaruh yang siginifikan antara variabel biaya distribusi terhadap peningkatan volume penjualan jasa barang di JNE Kuningan. Hasil penelitian ini sejalan dengan penelitian yang dilakukan oleh (Rasyid \& Suzan, 2018:1) yang menyatakan bahwa "Biaya distribusi memiliki pengaruh yang signifikan dengan arah positif terhadap penjualan perusahaan manufaktur sektor food and beverage yang terdaftar di Bursa Efek Indonesia tahun 2012-2016.”.

\section{KESIMPULAN DAN SARAN}

\section{Kesimpulan}

Berdasarkan identifikasi masalah, hipotesis dan hasil pengujian yang telah dilakukan untuk mengetahui pengaruh Biaya Distribusi (X) terhadap Volume Penjualan (Y) maka dapat disimpulkan sebagai berikut:

1. Biaya distribusi di JNE Kuningan mengalami perkembangan di setiap bulannya, terdapat kenaikan dan penurunan biaya distribusi atau mengalami fluktuasi disetiap bulannya dari tahun 2017 sampai dengan tahun 2019, dengan biaya distribusi tertinggi yang dikeluarkan pada bulan bulan juli tahun 2019 dan biaya distribusi terendah yang dikeluarkan oleh JNE Kuningan adalah pada bulan januari tahun 2017 yang di dapat dari data laporan laba rugi bulanan (periode 2017-2019) di JNE Kuningan.

2. Volume penjualan di JNE Kuningan mengalami perkembangan di setiap bulannya, terdapat kenaikan dan penurunan volume penjualan atau mengalami fluktuasi disetiap bulannya dari tahun 2017 sampai dengan tahun 2019 , dengan volume penjualan tertinggi yang didapat pada bulan juli tahun 2019 dan volume penjualan terendah yang diterima oleh JNE Kuningan yang adalah pada bulan januari tahun 2017 yang di dapat dari data laporan laba rugi bulanan (periode 2017-2019) di JNE Kuningan.

3. Hasil uji hipotesis secara parsial antara variabel $X$ (Biaya Distribusi) terhadap Y (Volume Penjualan) menunjukkan bahwa terdapat adanya 
pengaruh yang signifikan serta mempunyai arah yang positif antara biaya distribusi terhadap peningkatan volume penjualan jasa barang di JNE Kuningan.

\section{Saran}

Berdasarkan kesimpulan diatas, penulis mencoba memberikan saran yang dapat memberikan manfaat bagi peneliti selanjutnya. Adapun saran tersebut adalah sebagai berikut:

1. Peneliti selanjutnya disarankan untuk memperbaiki kekurangan-kekurangan yang terdapat dalam penelitian ini.

2. Penelitian selanjutnya diharapkan dapat menambahkan sampel yang digunakan dan memperluas penelitian bukan hanya terbatas pada PT JNE saja sehingga hasil data yang lebih baik.

3. Bagi peneliti selanjutnya, penulis menyarankan agar peneliti dapat menambahkan atau merubah kembali Variabel Y (Dependen) ataupun Variabel X (Independen) lagi selain dari biaya distribusi dan volume penjualan untuk lebih mengetahui seberapa besar pengaruh variabel lain seperti variabel biaya logistik yang di dalamnya terdapat biaya promosi, biaya pergudangan, biaya pemeliharaan dan biaya lainnya yang tidak di ujikan

\section{DAFTAR PUSTAKA} dalam penelitian ini.

\section{Jurnal:}

Devi, Lie, D., Butarbutar, M., \& Halim, F. (2017). Peranan Harga Dan Biaya Distribusi Terhadap Volume Penjualan Pada Pt Permata Niaga Cabang Pematangsiantar. Maker, 3(2), 19-26. Diambil dari https://maker.ac.id/index.php/maker/article/download/63/63

Gusrizaldi, R., \& Komalasari, E. (2016). Analisis Faktor-Faktor Yang Mempengaruhi Tingkat Penjualan Di Indrako Swalayan Teluk Kuantan. Jurnal Valuta, 2(2), 286303. https://doi.org/10.1207/s15327914nc5502_1

Kurnia, Y. (2017). Pengaruh Biaya Pemasaran Terhadap Volume Penjualan, 04(01), $168-176$.

Lanen, W. N., Anderson, S. W., \& Maher, M. W. (2017). Dasar-dasar Akuntansi Biaya (Edisi 4 Buku 1). Jakarta: Salemba empat.

Mulyadi. (2015). Akuntansi Biaya. Yogyakarta: Sekolah Tinggi Ilmu Manajemen YKPN.

Putra, I. G. S., Susila, G. P. A. J., \& Yulianthini, N. N. (2016). Pengaruh Biaya Produksi, Biaya Promosi, Dan Biaya Distribusi Terhadap Penjualan. Jurnal Manajemen Indonesia, 4(1). Diambil dari https:/ejournal.undiksha.ac.id/index.php/JMI/article/view/6765/4624

Rasyid, R. A., \& Suzan, L. (2018). Pengaruh Biaya Promosi Dan Biaya Distribusi Terhadap Penjualan (Suatu Studi pada Perusahaan Manufaktur Sektor Food and Beverage yang Terdaftar di Bursa Efek Indonesia 2012-2016). Jurnal AKSARA PUBLIC, 2(Agustus), 1-11. Diambil dari http://akrabjuara.com/index.php/akrabjuara/article/download/240/175/ 